\title{
Chemistry of different Amazonian water types for river classification: a preliminary review
}

\author{
E. A. Ríos-Villamizar ${ }^{1,3}$, M. T. F. Piedade ${ }^{1}$, J. G. Da Costa ${ }^{1}$, \\ J. M. Adeney ${ }^{2}$ \& W. J. Junk ${ }^{3,4}$ \\ ${ }^{1}$ Instituto Nacional de Pesquisas da Amazônia (INPA), Brazil \\ ${ }^{2}$ US Agency for International Development, and Duke University, USA \\ ${ }^{3}$ Universidade do Estado do Amazonas (UEA), Brazil \\ ${ }^{4}$ Instituto Nacional de Ciência e Tecnologia em Áreas Úmidas \\ (INCT-INAU-UFMT), Brazil
}

\begin{abstract}
Water chemistry provides important parameters for the study of river ecology and management options of rivers and connected wetlands. Sioli, in the 1950s, established three water types (whitewater, blackwater and clearwater) for explaining limnological characteristics of the large Amazonian rivers, and related the physico-chemical parameters of these water types with the geological properties of their basins; a landscape ecology approach. Today, an increasing amount of hydrochemical data indicate that the chemical composition of Amazonian water bodies varies much more than assumed by Sioli. Nonetheless, due to its simplicity for describing the natural physico-chemical variability of Amazonian rivers, his classification is still valid. Our analysis, based in literature and field work, allowed to distinguish well among the three classical water types and to provide new preliminary insights about the limnological classification of Amazonian rivers in order to subsidize the sustainable management of water resources and wetlands.

Keywords: Amazon basin, river classification, water hydrochemistry, landscape ecology.
\end{abstract}

\section{Introduction}

Water chemistry provides important parameters for quantifying biogeochemical cycles and determines management options in river systems and wetlands. Pre- 
Columbian populations categorized Amazonian rivers by the color of their water, and both native and colonial inhabitants of the Amazon knew that water color was related to specific ecological properties such as fish richness or soil fertility (Junk et al. [1]). The first scientific classification of Amazonian water bodies was elaborated in the 1950s by Sioli [2]. He used water color, transparency, $\mathrm{pH}$ and electrical conductance to explain limnological characteristics of the large Amazonian rivers. The innovative aspect of his classification was the correlation of these characteristics to the geological and geomorphological properties of the river catchments, an approach used today in landscape ecology.

Whitewater rivers (such as the Amazon main course and the Juruá, Japurá, Purus, and Madeira) are turbid, with water transparency (Secchi depth) that varies between 20 and $60 \mathrm{~cm}$, and have their origins in the Andes, from which they transport large amounts of nutrient-rich sediments. Their waters have nearneutral $\mathrm{pH}$ and relatively high concentrations of dissolved solids indicated by the electric conductivity that varies between $40-140 \mu \mathrm{S} \mathrm{cm}^{-1}$. Blackwater rivers (such as the Negro River) drain the Precambrian Guiana shield, which is characterized by large areas of white sands (podzols). Their water transparency is about $60-120 \mathrm{~cm}$, with low quantities of suspended matter but with high amounts of humic acids that give the water a brownish-reddish color. The $\mathrm{pH}$ values of such rivers are in the range of 4-5 and their electrical conductivity is $<20 \mu \mathrm{S} \mathrm{cm}^{-1}$. The floodplains of blackwater rivers are of low fertility and are locally called igapós.

Clearwater rivers (such as the Tapajós and Xingu Rivers) have their upper catchments in the cerrado region of the Central Brazilian archaic shield. The transparency of their greenish waters is above $150 \mathrm{~cm}$, with low amounts of sediments and dissolved solids and electrical conductivity that is in the range of $10-20 \mu \mathrm{Sm}^{-1}$, and $\mathrm{pH}$ that varies between 6 and 7 in large rivers. The floodplains of clearwater rivers are of intermediate fertility and also called igapós.

This simplified classification has dominated until today the scientific discussion about limnology and ecology of the Amazon basin, but Sioli's classification was based only on a very limited data base. In the meantime, the situation has changed dramatically. The National Amazon Research Institute INPA has conducted many limnological studies and hosted high-level, national and international limnological projects, such as the cooperation with the MaxPlanck-Institute for Limnology in Plön, Germany [3-5], and the CAMREX expeditions of the University of Seattle [6-8].

The aim of this paper is to analyze a preliminary data base about water chemistry of some Amazonian rivers and streams under Sioli's classification criteria, and provide some new insights in the limnological classification of Amazonian rivers and streams.

\section{Material and methods}

From literature we collected some preliminary data available on hydrochemistry of rivers and streams. In addition we collected water samples in the course of 
four field surveys during the periods of 27th October-3rd November 2009, 1st-7th March 2010, 26th September-3rd October 2010 and 3rd-12th December 2010 around the middle/lower area of the Jutaí, Tefé, Juruá and Tapajós river basins, respectively (fig. 1). The transparency (m) values were measured using the Secchi disk, and the electrical conductivity $\left(\mu \mathrm{S} \mathrm{cm}^{-1}\right.$ at $\left.25^{\circ} \mathrm{C}\right), \mathrm{pH}$, and Dissolved Oxygen $\left(\mathrm{mg} \mathrm{O}_{2} \mathrm{l}^{-1}\right)$ values were measured in the field using WTW instruments. In the laboratory of the INPA in Manaus (Brazil) were analyzed the water samples to obtain the values of the major cations such as $\mathrm{Ca}\left(\mathrm{mg} \mathrm{l}^{-1}\right), \mathrm{Mg}$ $\left(\mathrm{mg} \mathrm{l}^{-1}\right)$, $\mathrm{Na}\left(\mathrm{mg} \mathrm{l}^{-1}\right)$ and $\mathrm{K}\left(\mathrm{mg} \mathrm{l}^{-1}\right)$, and major anions such as Alkalinity (mg $\left.\mathrm{HCO}_{3} \mathrm{l}^{-1}\right), \mathrm{SO}_{4}\left(\mathrm{mg} \mathrm{l}^{-1}\right)$ and $\mathrm{Cl}\left(\mathrm{mg} \mathrm{l}^{-1}\right)$, as well as the values of water colour $\left(\mathrm{mg} \mathrm{Pt}^{-1}\right)$, Turbidity (NTU), Total Suspended Solids $\left(\mathrm{mg} \mathrm{l}^{-1}\right), \mathrm{PO}_{4}\left(\mathrm{mg} \mathrm{l}^{-1}\right), \mathrm{P}_{\text {tot }}$ $\left(\mathrm{mg} \mathrm{l}^{-1}\right), \mathrm{NH}_{4}\left(\mathrm{mg} \mathrm{l}^{-1}\right), \mathrm{NO}_{3}\left(\mathrm{mg} \mathrm{l}^{-1}\right), \mathrm{N}_{\text {tot }}\left(\mathrm{mg} \mathrm{l}^{-1}\right)$ and $\mathrm{Si}\left(\mathrm{mg} \mathrm{l}^{-1}\right)$. All the analyses were carried out by standard methods (APHA et al. [9]). Using Open Stat 4.0, a free code statistical program, a principal component analysis - PCA was accomplished in order to identify which variables are more important for the analysis, and for grouping water quality types (Mardia et al. [10]).

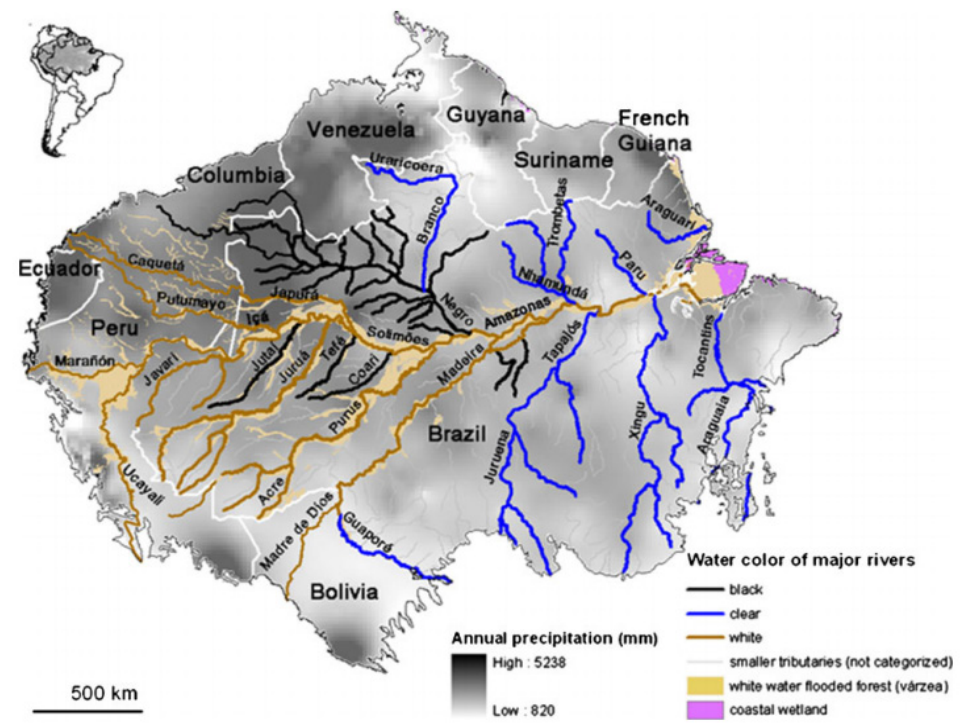

Figure 1: The distribution of major whitewater, blackwater, and clearwater rivers in the Amazon basin, from Junk et al. [1].

\section{Results}

In table 1 are presented the mean physico-chemical results of the analyzed water samples that were taken from some colorless streams (lower Tapajós basin) and Tapajós, Cuparí, Jutai, Tefé and Juruá Rivers. The physico-chemical characteristics of the Tefé and Juruá Rivers are similar to the classic/typical black and white waters, respectively (Furch and Junk [5]). The Tapajós River is 
characterized by having intermediate conditions between the white and black waters (Junk and Howard-Williams [11]). An intermediate and transitional pattern is also observed in the Jutai River. The colorless streams of the lower Tapajós basin show very acidic conditions and poverty in electrolytes resembling the classic black waters, with the exception of the color value which is very low in these kinds of streams.

Table 1: Mean physico-chemical characteristics of colorless streams (lower Tapajós river basin), and Tapajós, Cuparí, Jutaí, Tefé and Juruá rivers waters.

\begin{tabular}{|c|c|c|c|c|c|c|}
\hline \multirow[b]{2}{*}{ Variable } & \multicolumn{3}{|c|}{ Tapajós basin } & \multirow[b]{2}{*}{ Jutaí } & \multirow[b]{2}{*}{ Tefé } & \multirow[b]{2}{*}{ Juruá } \\
\hline & Tapajós & $\begin{array}{l}\text { Colorless } \\
\text { streams }\end{array}$ & Cuparí & & & \\
\hline $\mathrm{pH}$ & 6.56 & 4.39 & 6.26 & 5.96 & 5.03 & 7.27 \\
\hline $\begin{array}{l}\text { Electric conductivity } \\
(\mu \mathrm{S} / \mathrm{cm})\end{array}$ & 14.33 & 15.12 & 59.90 & 8.71 & 7.36 & 191.14 \\
\hline $\begin{array}{l}\text { Total Suspended } \\
\text { Solids (mg/l) }\end{array}$ & 10.56 & 0.35 & 6.33 & 46.56 & 7.90 & 51.42 \\
\hline $\mathrm{Ca}(\mathrm{mg} / \mathrm{l})$ & 0.52 & $<0.02$ & 2.85 & 0.54 & 0.71 & 32.55 \\
\hline $\mathrm{Mg}(\mathrm{mg} / \mathrm{l})$ & 0.26 & 0.06 & 0.71 & 0.15 & 0.22 & 4.42 \\
\hline $\mathrm{Na}(\mathrm{mg} / \mathrm{l})$ & 1.50 & 2.27 & 3.88 & 1.21 & 0.40 & 10.19 \\
\hline $\mathrm{K}(\mathrm{mg} / \mathrm{l})$ & 0.93 & 0.43 & 2.39 & 0.74 & 1.41 & 1.98 \\
\hline Total P (mg/l) & 0.010 & 0.013 & 0.020 & 0.079 & 0.033 & 0.080 \\
\hline $\mathrm{HCO}_{3}(\mathrm{mg} / \mathrm{l})$ & 8.80 & 2.07 & 21.96 & 8.78 & 6.86 & 106.14 \\
\hline $\mathrm{NO}_{3}(\mathrm{mg} / \mathrm{l})$ & 0.040 & $<0.010$ & 0.230 & 0.111 & 0.014 & 0.031 \\
\hline $\mathrm{NH}_{4}(\mathrm{mg} / \mathrm{l})$ & 0.19 & 0.12 & 0.38 & 0.21 & 0.13 & 0.062 \\
\hline Total N (mg/l) & 0.35 & 0.21 & 0.64 & 0.49 & 0.24 & 0.39 \\
\hline $\mathrm{SO}_{4}(\mathrm{mg} / \mathrm{l})$ & 0.30 & 0.24 & 7.72 & 0.61 & 4.20 & 2.56 \\
\hline Colour (mg/Pt/l) & 4.02 & 3.44 & 65.08 & 62.78 & 54.90 & 41.61 \\
\hline $\mathrm{Si}(\mathrm{mg} / \mathrm{l})$ & 5.25 & - & 9.12 & 3.35 & 0.33 & 5.78 \\
\hline $\mathrm{Cl}(\mathrm{mg} / \mathrm{l})$ & 0.53 & 2.50 & 1.78 & 1.28 & 0.85 & 4.75 \\
\hline
\end{tabular}

- = Not analyzed. 
Others authors such as Silva et al. [12] already observed colour values in the Tapajós River water around five times higher than the value of this study, similar to the values observed in the Jufari River water, which is considered one of the Negro River's tributaries showing the highest poverty of dissolved substances (Santos et al. [13]). We also observed similarities between the Jufari and Tapajós River mainly in terms of the variables $\mathrm{Cl}$ and total Fe. On the other hand, the values of the variables $\mathrm{pH}, \mathrm{Ca}, \mathrm{K}$ and $\mathrm{NH}_{4}$ are similar between Jufari River and the colorless streams of the lower Tapajós basin. However, the results of the Cuparí River, a Tapajós River's right bank tributary, are higher than usually is found in the Tapajós basin and the Amazon region itself, but these are in agreement with the findings of Sioli [14] especially for $\mathrm{pH}, \mathrm{Ca}, \mathrm{Mg}, \mathrm{SO}_{4}, \mathrm{Fe}$ and $\mathrm{Si}$.

In contrast to the Amazonian black waters which show pH-values below 5.0 and electrical conductivity less than $25 \mu \mathrm{S} \mathrm{cm} \mathrm{cm}^{-1}$, the typical Amazonian white waters are characterized as carbonate waters according to Furch and Junk [5], indicating richness in carbonates and calcium, $\mathrm{pH}$ above 6.5 and electrical conductivity more than $40 \mu \mathrm{S} \mathrm{cm} \mathrm{cm}^{-1}$. On the other hand, Sioli's observations of clear waters were based at the lower Tapajós and Arapiuns (Sioli $[2,15])$. Both rivers show typical high transparency because they are Ria lakes without major current, where sediments brought in by the rivers became already deposited. They do not represent the physico chemical conditions of the channels of these rivers, but those of Ria-lakes, which have been built in the large mouth bays of the black and clearwater tributaries of the Amazon River by the damming back of the river water because of the raise in sea-level after the last glacial period. Transparency of the Tapajós-water increases from $85 \mathrm{~cm}$ at Itaituba on Transamazon Highway to $245 \mathrm{~cm}$ at Santarém, $280 \mathrm{~km}$ far. The other parameters do not show major changes. We may assume that sediment load of the Tapajós has increased since Sioli's time because of increased erosion as a result of increased land use. But this will happen in future with other transparent rivers and streams and shows the limited value of transparency for river classification.

Furthermore, annual data sets show for some rivers considerable fluctuations in physico-chemical parameters, which makes the relation to a specific water type difficult, as shown for the Branco River (fig. 2).

Finally, the multivariate analysis indicated that the first three principal components account for over $65 \%$ of the variability in the data set. According to the first component, the more important variables are the major anions $(\mu \mathrm{eq} / \mathrm{L})$, $\mathrm{HCO}_{3}(\mu \mathrm{eq} / \mathrm{L})$, electrical conductivity $(\mu \mathrm{S} / \mathrm{cm})$, major cations $(\mu \mathrm{eq} / \mathrm{L}), \mathrm{Ca}$ $(\mu$ eq $/ \mathrm{L}), \mathrm{Mg}(\mu \mathrm{eq} / \mathrm{L}), \mathrm{Na}(\mu \mathrm{eq} / \mathrm{L}), \mathrm{eq} \% \mathrm{Ca}, \mathrm{pH}, \mathrm{Cl}(\mu \mathrm{eq} / \mathrm{L})$ and $\mathrm{K}(\mu \mathrm{eq} / \mathrm{L})$. Accounting to the second component are the total $\mathrm{N}(\mu \mathrm{eq} / \mathrm{L}), \mathrm{eq} \% \mathrm{Mg}, \mathrm{eq} \% \mathrm{Na}$, water colour $(\mathrm{mg} / \mathrm{Pt} / \mathrm{L})$, eq $\% \mathrm{SO}_{4}$ and eq $\% \mathrm{~K}$. The third component is constituted by eq $\% \mathrm{HCO}_{3}$, eq $\% \mathrm{Cl}$, transparency $(\mathrm{m})$ and total $\mathrm{P}(\mu \mathrm{eq} / \mathrm{L})$. All the loading values are above 0.2 or below -0.2 (fig. 3 and table 2 ). 


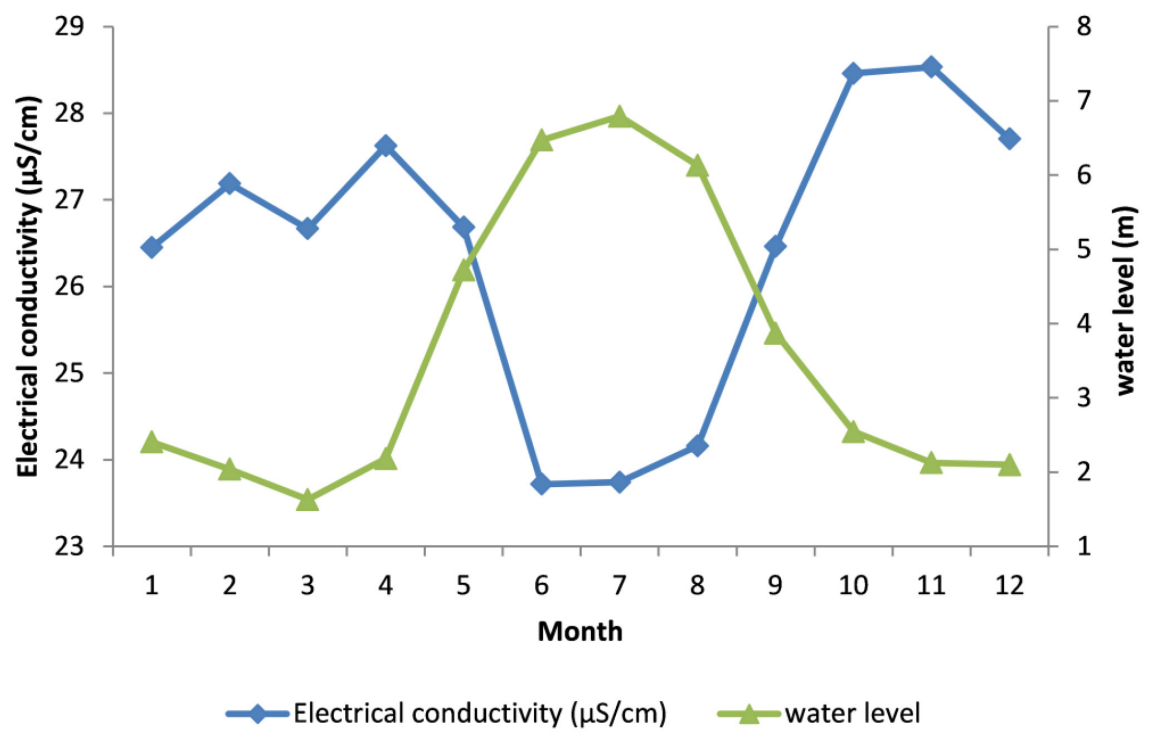

Figure 2: Water level fluctuations and seasonal variations of electrical conductivity in the Branco River at Caracarai. Monthly mean values from September 2003 to December 2009, according to data from ORE-HYBAm [16].

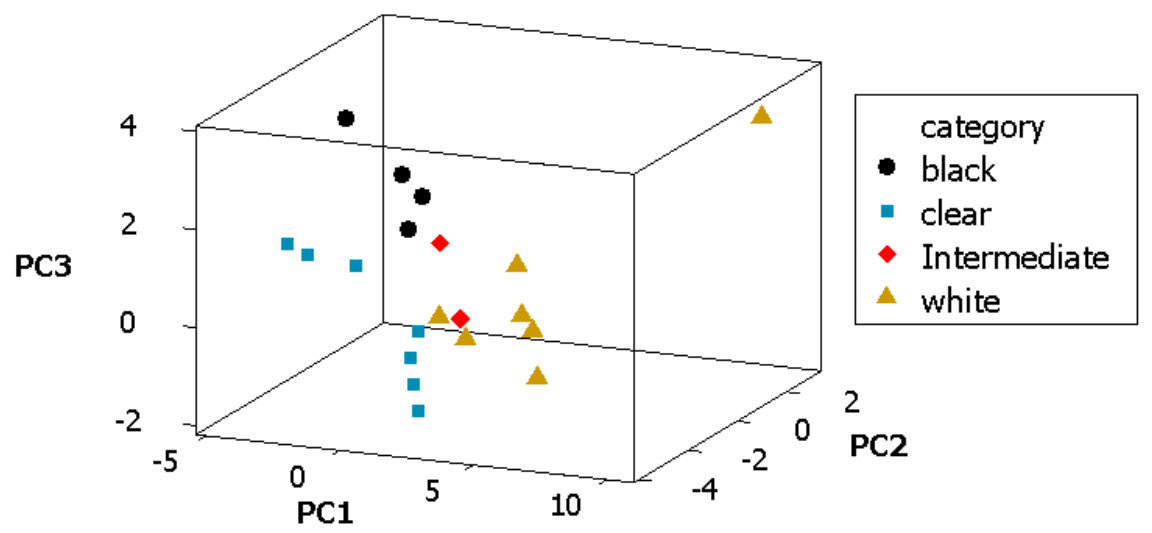

Figure 3: Scores plot of the PCA for the first (41.6\% of the variance), second $(14.1 \%)$ and third $(9.4 \%)$ component. 
Table 2: $\quad$ Rivers and streams used in the analysis (by water type).

\begin{tabular}{|l|l|l|}
\hline $\begin{array}{c}\text { Water type } \\
\text { (category) }\end{array}$ & River or stream name & \multicolumn{1}{c|}{ Source } \\
\hline $\begin{array}{l}\text { Blackwater } \\
\text { rivers }\end{array}$ & Negro, Tefé. & $\begin{array}{l}\text { Leenheer and Santos [17]; Junk and } \\
\text { Howard-Williams [11]; Furch and } \\
\text { Junk [5]. }\end{array}$ \\
\hline $\begin{array}{l}\text { Clearwater } \\
\text { rivers }\end{array}$ & $\begin{array}{l}\text { Tapajós, colorless } \\
\text { streams at lower } \\
\text { Tapajós River, } \\
\text { Branco, Araguaia, } \\
\text { Guaporé. }\end{array}$ & $\begin{array}{l}\text { Santos [18]; Stallard and Edmond } \\
{[19] ; \text { Santos } \text { et al. } \text { [13]; this study; }} \\
\text { INAU, unpubl. data. }\end{array}$ \\
\hline $\begin{array}{l}\text { Whitewater } \\
\text { rivers }\end{array}$ & $\begin{array}{l}\text { Solimões/Amazonas, } \\
\text { Juruá, Cuparí, } \\
\text { Tocantins. }\end{array}$ & $\begin{array}{l}\text { Leenheer and Santos [17]; Santos } \\
{[18] ; \text { Junk and Howard-Williams }} \\
\text { [11]; Richey et al. } \text { [8]; this study. }\end{array}$ \\
\hline $\begin{array}{l}\text { Intermediate } \\
\text { (other rivers) }\end{array}$ & Jutaí, Bóia. & Richey et al. [8]; this study. \\
\hline
\end{tabular}

INAU: Instituto Nacional de Ciência e Tecnologia em Áreas Úmidas.

\section{Discussion}

Ríos-Villamizar et al. [20] classified several rivers and streams using the relationship between major cations ( $\mathrm{mg} \%)$. They observed that the distribution of alkali and alkaline-earth metals allows distinguishing well among the three classical/typical water types and to categorize others rivers since, generally, the latter occupy intermediate positions among that three typical water types, showing hence a transitional character, fig. 4 .

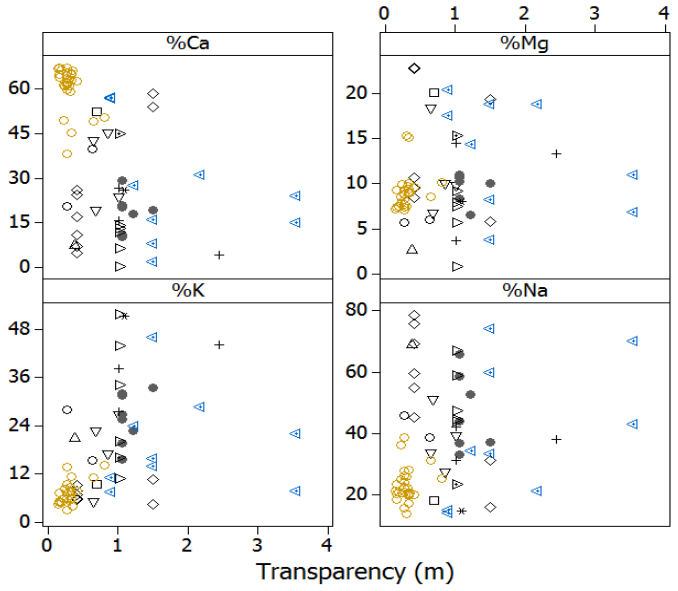

Water bodies and water color of major rivers

$\nabla$ Rivers and creeks (Carboniferous strips)

$\checkmark$ Amazon estuary

$\Delta$ Bóia river

$\checkmark$ Central Amazonian forest streams

D Centrai

O Jutaí river

+ Rivers and creeks (Southern peripheral Amazonia)

D Rivers and creeks (Transamazon highway)

Hefe river

'Tocantins river' tributaries

Figure 4: Relationship between the distribution of alkali and alkaline-earth metals and transparency of Amazonian rivers and streams, from RíosVillamizar et al. [20]. 
There are waters, along the Amazon Basin, where the chemical quality does not match with the optical attributes accordingly with the classical water type (e.g., Branco River and its tributaries, Copatana, Marauiá, Cuparí and Tocantins Rivers among others) and this indicates anew the problems arising when river types are given generalised designations (Geisler and Schneider [21]).

Today, road construction in the Amazon allows access to low-order rivers in remote areas that were previously inaccessible to Sioli and other limnologists. The Central Amazonian tertiary/Cenozoic sediment basin and some of the plateaus, such as the Chapada dos Parecis along the highway from the cities Cuiabá to Porto Velho (Furch and Junk [4]), are rather homogeneous, but other areas of the archaic/Pre-Cambrian shields show a large and sometimes smallscale geological complexity which is reflected by a large hydrochemical variability as shown by the hydrochemical transects South to North from Cuiabá to Manaus (Furch and Junk [4]), Manaus to Caracarai (Furch [22]), and the East to West transect along the Transamazon Highway from Altamira to Humaitá (Furch [3, 23]). With increasing river order, this complexity becomes hidden, because the river provides the integration of all types of waters of the entire catchment by mixing waters of different quality. Also, the geology of the preAndean zone is also rather heterogeneous with large old sedimentation areas (paleo-varzeas) of different ages. These sediments are strongly weathered, but still have a higher bioelement content than the tertiary sediments of the central Amazon basin and the soils on the archaic shields.

Rivers draining archaic/Pre-Cambrian shields, e.g. Branco River in Roraima State, integrate tributaries of different water quality including blackwater tributaries, and present at the mouth a mixed water whose physico-chemical parameters vary during the annual cycle.

Possibly due to the influence of the Amazon River's flood pulse, the single samples that were collected at the lower section of some Amazonian black-water rivers such as the Negro, Tefé, Uatumã and Urubu in Brazil; Nanay in Peru and some streams in Colombia can have ionic composition and/or $\mathrm{pH}$-values similar to the white waters rivers and not like the typical Amazonian black waters rivers, and this fact do not allow getting a general statement about their chemical category. The low electrical conductivity values can be responsible for this phenomenon because in electrolyte-poor waters, a little oscillation of $\mathrm{Ca}$ or $\mathrm{HCO}_{3}$ content can make a high variation of the respective percentage, which in the Solimões/Amazon river water would not affect the percentage in a noticeable way. The heterogeneous geology of the different tributaries may also be an explanation. For instance, the Jatapu River, an Uatumã River's lower tributary, crosses the Nova Olinda/Carboniferous Formation and probably this fact is responsible for alterations in the physico-chemical characteristics of the Uatumã River's lower part.

The most characteristic water type is the Amazon whitewater deriving from the Andes. The water of the main stem becomes diluted from about 120 $200 \mu \mathrm{S} \mathrm{cm}^{-1}$ near the Andes to $40-70 \mu \mathrm{S} \mathrm{cm}{ }^{-1}$ at Santarem by blackwater and clearwater tributaries [19, 24-29, this study], but it continues to be a turbid, nearly neutral, relatively electrolyte-rich water dominated by carbonates of alkali 
earth metals. The importance of the total amount and relationship of alkali and alkali-earth metals and carbonates can be considered as an essential chemical parameter for the classification of Amazonian water types (Furch and Junk [5]). If we do this, some rivers, draining the carboniferous stripes at the lower Amazon, where many dissolved substances can be found in higher values than usual (Sioli [14]), such as some tributaries of the Tapajós and Tocantins Rivers, the Tocantins River itself, as well as some rivers of the Andean/Pre-Andean zone such as Zongo River in the upper Madeira basin (ORE-HYBAm) have to be considered as whitewater rivers despite of a low load of suspended sediments. Even far away from the Andes, the middle Tocantins River's major tributaries and the Tocantins River itself (ELETRONORTE/THEMAG [30]), share some chemical characteristics such as electrical conductivity, $\mathrm{pH}$ and ionic composition with the classical Andean white-water rivers.

A similarly characteristic water type is the Negro River black water which, originated on the Precambrian shield of the northern region of the Amazon basin, is a typical representative of the Amazonian black waters (Furch and Junk [5]). Its transparent red-brown colour originates from a high content of dissolved humic substances which is about ten times higher than in the Solimões/Amazon River, the water is poor in nutrients and electrolytes with dominance of sodium among the major cations, presenting low alkalinity. The $\mathrm{pH}$ and electrical conductivity values are less than 5.0 and $25 \mu \mathrm{S} \mathrm{cm}^{-1}$, respectively.

The rivers of the Sioli's clear water type have their upper catchments in the Central Brazilian and Guiana archaic/Pre-Cambrian shields and are characterized by $\mathrm{pH}$-values that vary between 5.0 and 7.0, electrical conductivity is in the range of $10-53.6 \mu \mathrm{S} \mathrm{cm}^{-1}$, the water transparency can reach up to $355 \mathrm{~cm}$ or still higher; but transparency values less than $100 \mathrm{~cm}$ are also common in these rivers. However, we consider the total amount and relationship of alkali and alkali-earth metals and carbonates as a more stable and stronger parameter for the water classification than the amount of suspended solids.

\section{Conclusions}

The combination of several parameters such as the amount and relationship between alkali and alkali-earth metals, and major anions especially bicarbonates and chlorides, electrical conductivity, $\mathrm{pH}$, total $\mathrm{N}$, water colour, suspended sediment load as transparency and total $\mathrm{P}$ allow to distinguish the three classical water types (white, black and clear) and other water bodies with intermediate position. The distribution of alkali and alkaline-earth metals and major anions is especially useful for the distinction of whitewater, blackwater and clearwater categories. Higher variability is shown by water bodies that not fit inside these three classic categories. Therefore, many rivers and streams have to be considered as "mixed waters" resulting from the influence of lower order tributaries with different physico-chemical properties of their waters. 


\section{Acknowledgements}

We thank the Nuclei Excellency Support Projects (PRONEX), INPA/MaxPlanck project, and the Ecology, Monitoring and Sustainable Use of Wetlands Group (MAUA), as well as the Instituto Nacional de Ciência e Tecnologia em Áreas Úmidas (INCT-INAU-UFMT) and "CAPES/CNPq - IEL Nacional Brasil" for financial support. We thank also the personnel of the Environmental Chemistry Laboratory at INPA (CPCRH) for assistance with laboratory analyses. The first author is a $\mathrm{PhD}$ student at Climate and Environment Program (INPA/UEA).

\section{References}

[1] Junk, W.J., Piedade, M.T.F., Schöngart, J., Cohn-Haft, M., Adeney, J.M. and Wittmann, FA., Classification of Major Naturally-Occurring Amazonian Lowland Wetlands. Wetlands, 31, pp. 623-640, 2011.

[2] Sioli, H., Über Natur und Mensch im brasilianischen Amazonasgebiet. Erdkunde, 10(2), pp. 89-109, 1956b.

[3] Furch, K., Hydrogeochemistry of Amazonian freshwaters along the transamazônica in Brazil. Zbl. Geol. Paläont, Teil I(9/10), pp. 1485-1493, 1986.

[4] Furch, K. and Junk, W.J., Water chemistry and macrophytes of creeks and rivers in southern Amazonia and the central Brazilian Shield. Tropical Ecology and Development (Part 2), ed. Furtado II, The international Society of tropical Ecology: Kuala Lumpur, pp. 771-796, 1980.

[5] Furch, K. and Junk, W.J., Physicochemical Conditions in the Floodplains (Chapter 4). The Central Amazon Floodplain: Ecology of a Pulsing System, ed. W.J. Junk, Springer-Verlag: Berlin Heidelberg, pp. 69-108, 1997.

[6] Martinelli, L.A., Victoria, R.L., Devol, A.H., Richey, J.E. and Forsberg, B.R., Suspended sediment load in the Amazon basin: An overview. GeoJournal, 19(4), pp. 381-389, 1989.

[7] Richey, J.E., Hedges, J.I., Devol, A.H., Quay, P.D., Victoria, R., Martinelli, L. and Forsberg, B.R., Biogeochemistry of carbon in the Amazon river. Limnol. Oceanogr., 35(2), pp. 352-371, 1990.

[8] Richey, J.E., Victoria, R.L., Hedges, J.I., Dunne, T., Martinelli, L.A., Mertes, L. and Adams, J., Pre-LBA Carbon in the Amazon River Experiment (CAMREX). Data Set Online. Oak Ridge National Laboratory Distributed Active Archive Center, Oak Ridge, Tennessee, U.S.A. doi:10.3334/ORNLDAAC/904, 2008. http://daac.ornl.gov

[9] APHA., AWWA and WEF., (eds). Standard Methods for the Examination of Water and Wastewater, $21^{\text {st }}$ Ed., American Public Health Association: Washington, 2005.

[10] Mardia, K.V., Kent, J.T. and Bibby, J.M., Multivariate Analysis, Academic Press: New York, pp. 213-254, 1979.

[11] Junk, W.J. and Howard-Williams, C., Ecology of aquatic macrophytes in Amazonia (Chapter 10). The Amazon - Limnology and landscape ecology of 
a mighty tropical river and its basin, ed. H. Sioli, Dr. W. Junk Publishers: Dordrecht, Boston and Lancaster, pp. 269-293, 1984.

[12] Silva, M.S.R., Brandão da Cunha, H.B., Miranda, S.A.F., Santana, G.P. and Pascoaloto, D., Química das águas de superfície dos rios da bacia Amazônica: uma contribuição para classificação de acordo com seus usos preponderantes. Anais XIX Simpósio brasileiro de recursos hídricos, ABRH: Maceió, Brasil, pp. 1-11, 2011.

[13] Santos, U.M., Bringel, S.R.B., Bergamin Filho, H., Ribeiro, M.N.G. and Bananeira, M., Rios da bacia Amazônica. I. Afluentes do rio Negro. Acta Amazonica, 14(1-2), pp. 222-237, 1984.

[14] Sioli, H., Hydrochemistry and geology in the Brazilian Amazon region. Amazoniana, 1(3): pp. 267-277, 1968.

[15] Sioli, H., O Rio Arapiuns. Estudo limnológico de um corpo d'água da região do Terciário, Plioceno, Série das Barreiras, do baixo Amazonas. Bol. Técn. Inst. Agr. Norte, 32, pp. 1-116, 1956a.

[16] Environmental Research Observatory - ORE-HYBAM (Geodynamical, hydrological and biogeochemical control of erosion/alteration and material transport in the Amazon basin). Database Web Site, www.ore-hybam.org.

[17] Leenheer, J.A. and Santos, U.M., Considerações sobre os processos de sedimentação na água preta ácida do Rio Negro (Amazônia Central). Acta Amazonica, 10(2), pp. 343-355, 1980.

[18] Santos, A., Limnologia do sistema Tocantins-Araguaia, aspectos físicos e biogeoquímicos. Tese de doutorado. UFSCar, São Carlos, Brasil, 257pp, 1983.

[19] Stallard, R.F. and Edmond, J.M., Geochemistry of the Amazon. 2. The influence of geology and weathering environment on the dissolved load. J. Geophys. Res., 88(C14), pp. 9671-9688, 1983.

[20] Ríos-Villamizar, E.A., Piedade, M.T.F., Wittmann, F., Carvalho, T.M. and Junk, W.J., Improvement of a Major Naturally-Occurring Amazonian Lowland Wetlands Classification by means of the Classical Knowledge of River Water Hydrochemistry: Major Cations. Proc. of the $1^{\text {st }}$ Int. Conf. On Traditional Knowledge for Water Resources Management, eds. S.S. Yazdi, A. Bahri, and E.A. Yazdi, CIVILICA: Yazd, Iran, \#45, pp. 354-360, 2012.

[21] Geisler, R. and Schneider, J., The element matrix of Amazon waters and its relationship with the mineral content of fishes (determination using Neutron Activation Analysis). Amazoniana, 6(1), pp. 47-65, 1976.

[22] Furch, K., Water chemistry of the Amazon basin: The distribution of chemical elements among freshwaters (Chapter 6). The Amazon Limnology and landscape ecology of a mighty tropical river and its basin, ed. H. Sioli, Dr. W. Junk Publishers: Dordrecht, Boston and Lancaster, pp. 167-199, 1984.

[23] Furch, K., Hidrogeochemistry of freshwaters crossed by the Transamazon highway, northern Brazil. Amazoniana, 9(3), pp. 371-409, 1985.

[24] Gessner, F., Der Elektrolytgehalt des Amazonas. Arch. Hydrobiol., 58(4), pp. 490-499, 1962. 
[25] Gibbs, R.J., The geochemistry of the Amazon River system: Part I. The factors that control the salinity and the composition and concentration of the suspended solids. Geol. Soc. Am. Bull., 78, pp. 1203-1232, 1967.

[26] Oltman, R.E., Reconnaissance investigations of the discharge and water quality of the Amazon River. U.S. Geological Survey, 552, pp. 1-16, 1968.

[27] Santos, U.M. and Ribeiro, M.N.G., A hidroquímica do rio SolimõesAmazonas. Acta Amazonica, 18(3-4), pp. 145-172, 1988.

[28] Duque, S.R., Ruiz, J.E., Gómez, J. and Roessler, E., Limnología. Zonificación Ambiental para el Plan Modelo Colombo-Brasilero (eje Apaporis-Tabatinga): PAT, ed. IGAC, Linotipia: Bogotá, Colombia, pp. 71-134, 1997.

[29] Palma-Silva, L., Efecto de la conectividad del río Amazonas en la ecología del fitoplancton en lagos Amazónicos. Tesis de Maestría. Universidad Nacional de Colombia, Leticia, Colombia, 81pp, 2011.

[30] ELETRONORTE/THEMAG., Limnological planning and monitoring of the Tocantins river in the section where the Serra Quebrada reservoir is to be built, ABRH/IWRA/UNEP/UNESCO, pp. 1-15, 1989. 